\title{
PARLAMENTARYZM DOBY JANA III SOBIESKIEGO
}

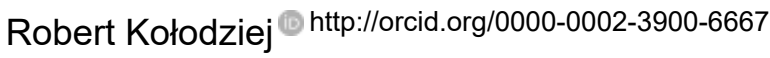 \\ Uniwersytet Wrocławski
}

\section{ABSTRACT \\ PARLIAMENTARY SYSTEM IN JOHN III SOBIESKI'S TIME}

The parliamentary system under John III Sobieski stands out against other eras and has many distinguishing characterstics. Initially, the parliament functioned more effectively at that time than during the reign of Michał Korybut Wiśniowiecki, but its efficiency was steadilly falling. The successes of parliaments were bought at the price of several months of deliberation. The desperate nobility looked for legal solutions, but without violating the liberum veto principle they were not very effective. The increase in the importance of dietines meant that they gathered much more often than before. The limita (continuing the debate after a few weeks' break) allowed for frequent dietine meetings without issuing a new royal document (uniwersat). However, dietines also experienced a period of political struggle, which can be seen in the increasing number of interrupted dietines. "Senatorial councils" functioned efficiently, but their competences were limited. The king's attempts to replace parliaments with councils could' not succeed.

Keywords: John III Sobieski, parliament, senate, dietine, parliamentary system, Polish-Lithuanian Commonwealth.

Słowa kluczowe: Jan III Sobieski, sejm, senat, sejmiki, system parlamentarny, Rzeczpospolita Obojga Narodów.

System parlamentarny za panowania Jana III (1674-1696) cechował się wieloma odrębnościami, które odróżniały go zarówno od wcześniejszych czasów Wazów i Michała Korybuta, jak i od następującej po nim epoki saskiej ${ }^{1}$. Sporo negatywnych zjawisk, jakie można zaobserwować w systemie polityczno-ustrojowym

1 Zob. H. Olszewski, Ustrój i doktryna w Rzeczypospolitej czasów Jana III Sobieskiego, „Studia Historyczne" 1985, nr 26, s. 15-28; idem, The Political System and Political Thought in Poland During the Reign of John Sobieski, ,Acta Poloniae Historica” 1985, nr 52, s. 87-103. 
Rzeczypospolitej w ostatnim dwudziestopięcioleciu XVII wieku, miało korzenie w latach wcześniejszych. Do pierwszego załamania systemu parlamentarnego doszło w schyłkowym okresie rządów Jana Kazimierza, a katalizatorem stał się niewątpliwie rokosz Jerzego Lubomirskiego ${ }^{2}$. Kryzys ustrojowy trwał w następnych latach, ciągnąc się przez całe panowanie Michała I, aż do sejmu pacyfikacyjnego w 1673 $\mathrm{roku}^{3}$. Elekcja Jana Sobieskiego nie dawała dużej nadziei na uspokojenie sytuacji wewnętrznej. Walkę wygrał bowiem jeden z przywódców znienawidzonej wśród części społeczeństwa szlacheckiego fakcji malkontentów. Oznaczało to, że konflikty polityczne nie ustaną, a dotychczasowi zaufani dworu przejdą do opozycji wobec nowego monarchy. Stało się to widoczne już na polu elekcyjnym, gdy wielu przedstawicieli Wielkiego Księstwa Litewskiego, na czele z wszechwładnymi Pacami, dążyło do zakwestionowania aktu wyboru nowego monarchy. Szczęśliwe zakończenie sejmu elekcyjnego było możliwe jedynie dzięki zastosowanemu wybiegowi proceduralnemu, gdy uznano, iż wszystkie uchwały podjęte przed złożeniem protestu (w tym pacta conventa) są ważne ${ }^{5}$. Nie uspokoiło to naturalnie niezwykle ostrych konfliktów politycznych, które rzutowały na funkcjonowanie całego systemu parlamentarnego. Oparty wszak na kompromisie i dobrej woli obu stron mógł on sprawnie funkcjonować jedynie w wypadku utrzymywania się wysokiej kultury politycznej jego uczestników. Tymczasem wcześniejsze działania dworu Jana Kazimierza, stosującego masową korupcję w życiu publicznym, demoralizowały naród polityczny. Doprowadziło to w drugiej połowie XVII wieku do rosnącego zaangażowania obcych dyplomatów w wewnętrzne życie polityczne Rzeczypospolitej. Przedstawiciele Brandenburgii-Prus poprzez swoich rezydentów próbowali ingerować w prace sej$\mathrm{mu}$, posiadali też spore wpływy na sejmikach ${ }^{6}$. W kraju toczyła się ponadto rywalizacja francusko-habsburska, w której to jedna, to druga strona wspierała działalność opozycji antykrólewskiej. Sobieski musiał dostosowywać swój kurs polityczny do nastrojów społecznych i nie miał zamiaru ostentacyjnie postępować wbrew woli szlachty, tym bardziej że zależało mu na przywróceniu pewnej stabilności w rozchwianej konstrukcji ustrojowej Rzeczypospolitej.

Należy uznać, że działania króla przyniosły w tym zakresie pewne pozytywne efekty. Polegały one przede wszystkim na mozolnej pracy organizacyjnej. $Z$ pewnością Sobieski był zdolniejszy i bardziej energiczny niż Michał Korybut ${ }^{7}$, które to

2 S. Ochmann-Staniszewska, Z. Staniszewski, Sejm Rzeczypospolitej za panowania Jana Kazimierza Wazy. Prawo - doktryna - praktyka, t. 2, Wrocław 2000, s. 310-311.

3 Szerzej na ten temat zob. L. Wierzbicki, O zgodę w Rzeczypospolitej. Zjazd warszawski i sejm pacyfikacyjny $1673 \mathrm{r}$., Lublin 2006.

${ }_{4}$ Zob. J. Woliński, Epilog elekcji 1674 r., Kraków 1952.

$5 \quad$ R. Kołodziej, Sejm elekcyjny w 1674 roku-precedens w procedurze sejmowej? [w:] Wokót wolnych elekcji w państwie polsko-litewskim XVI-XVIII w., red. M. Markiewicz, D. Rolnik, F. Wolański, Katowice 2016, s. 333-341.

${ }^{6}$ A. Kamieński, Wplywy polityczne Brandenburgii-Prus na sejmiku średzkim za panowania Jana III Sobieskiego [w:] Między barokiem a oświeceniem. Parlamentaryzm, red. B. Krysztopa-Czupryńska, J. Kiełbik, Olsztyn 2016, s. 127-142.

7 O bezradności Michała wobec wypadków toczących się w Rzeczpospolitej świadczy choćby nikła jego rola w czasie trwania konfederacji gołąbskiej, zob. A. Przyboś, Michat Korybut Wiśniowiecki 
cechy były niezbędne, aby przygotować grunt do szczęśliwego kończenia sejmów. Potrzebne było do tego również odpowiednie zaplecze polityczne, które u progu rządów Jana III prezentowało się bardzo skromnie. Król opierał się początkowo na szlachcie ruskiej, małe wpływy posiadał w Wielkopolsce, jeszcze gorzej sytuacja przedstawiała się na Litwie, której znaczna część znajdowała się pod politycznym wpływem skonfliktowanych z monarchą Paców ${ }^{8}$. Sobieski rekompensował to zapleczem w wojsku koronnym i częściowo litewskim ${ }^{9}$, a jako zwycięski wódz mozolnie starał się zaskarbiać popularność wśród szlachty. Powoli, w miarę możliwości wprowadzał też do senatu swoich zaufanych, aby zyskać szersze zaplecze w tej ważnej instytucji ${ }^{10}$. Trzeba jednak zauważyć, że podejmowane przez Sobieskiego wysiłki, mające pomóc mu w sprawowaniu rządów, opierały się raczej na wykorzystywaniu istniejących możliwości prowadzenia skutecznej działalności politycznej. Brakowało natomiast propozycji w sferach ustrojowych, mających na celu choćby ograniczone, systemowe reformy. Być może był to zabieg celowy, aby nie dawać opozycji broni do ręki i nie wzbudzać wśród szlachty podejrzeń i oskarżeń o próby wprowadzenia absolutum dominium. Wreszcie pewne znaczenie dla funkcjonowania systemu politycznego miała sytuacja międzynarodowa i trwająca wojna z Imperium Osmańskim. Zagrożenie kraju król wykorzystywał, apelując do szlachty o rozwagę i zgodę wewnętrzną. Początkowo dawało to zresztą pozytywne rezultaty i hamowało próby zrywania sejmów.

Analizując system parlamentarny omawianego okresu, należy zwrócić uwagę nie tylko na sejm, ale również na pozostałe jego elementy. $Z$ pewnością niezwykle istotną rolę odgrywały w nim sejmiki przedsejmowe oraz relacyjne. Nie można też pomijać rad senatu, zwoływanych przez Sobieskiego dużo chętniej i częściej niż sejm. Wprawdzie w tym czasie kompetencje rad senatu nie wzrosły, jednak pewne sygnały zdają się wskazywać, że Sobieski próbował podejmować działania mające na celu wzmocnienie ich pozycji w strukturze parlamentarnej.

Analizując pracę sejmu w omawianym okresie, trzeba zacząć od zmian, jakie wówczas zachodziły w regulaminie i procedurze obrad. Część z nich doczekała się

1640-1673, Kraków 2007 (wyd. 2), s. 197; podobnie o roli króla wypowiada się L. Wierzbicki, Pospolite ruszenie $w$ Polsce $w$ drugiej polowie XVII wieku. Ostatnie wyprawy z lat 1670-1672, Lublin 2011, s. 267.

Zob. K. Bobiatyński, Michat Kazimierz Pac-wojewoda wileński, hetman wielki litewski. Dziatalność polityczno-wojskowa, Warszawa 2008; D. Konieczna, Pomiędzy Pacami, Radziwiltami i Sapiehami - polityczne wybory Aleksandra Hilarego Potubińskiego za panowania Jana III, „Klio” 2015, 35, nr 4, s. 3-18; K. Bobiatyński, $W$ walce o hegemonię. Rywalizacja polityczna w Wielkim Księstwie Litewskim w latach 1667-1674, Warszawa 2016; M. S awicki, Dom sapieżyński 1666-1685. Droga do hegemonii w Wielkim Księstwie Litewskim, Opole 2016; A.A. Majewski, Aleksander Hilary Polubiński (1629-1679), marszałek wielki litewski. Dziatalność polityczno-wojskowa, Warszawa 2017.

9 Hetmanem polnym litewskim był Michał Kazimierz Radziwiłł, szwagier Sobieskiego, z którym ten wiązał początkowo duże nadzieje, zob. J. Jaroszuk, Radziwitt Michat Kazimierz h. Trąby (16351680) [w:] Stownik biograficzny, t. 30, Wrocław-Warszawa-Kraków-Gdańsk-Łódź 1987, s. 293-299.

10 Nie uniknąl jednak Sobieski błędów, promując ludzi, którzy w późniejszym czasie stanowili trzon opozycji. Należeli do nich choćby Kazimierz i Benedykt Sapiehowie czy Michał Radziejowski; szerzej na ten temat zob. M. Sawicki, op. cit., s. 219-246; R. Kawecki, Kardynat Michat Stefan Radziejowski (1645-1705), Opole 2005, s. 74-87. 
zresztą zapisów w prawie pisanym i została potwierdzona odpowiednimi konstytucjami ${ }^{11}$. Stało się tak mimo niechęci szlachty do uchwalania nowych praw w zakresie funkcjonowania sejmu. Można jednak wskazać dwa najważniejsze czynniki, które skłoniły szlachtę do zmian.

Pierwszy z nich wynikał z wieloletnich dążeń Litwinów do organizowania sejmów na terenie Wielkiego Księstwa. Starania te zostały zwieńczone konstytucją 1673 roku, która nakazywała zwoływanie co trzeciego sejmu w Grodnie, z wyłączeniem sejmów konwokacyjnych, elekcyjnych oraz koronacyjnych. Litwini zażarcie bronili świeżo wywalczonego prawa do organizowania sejmów grodzieńskich, a wielkie poruszenie wśród litewskich obywateli wzbudziło jednorazowe przeniesienie obrad w 1685 roku z Grodna do Warszawy ${ }^{12}$. Wywołało to falę protestów, zakończoną uchwaleniem jeszcze jednej konstytucji potwierdzającej sejmy grodzieńskie ${ }^{13}$. Ocena decyzji na temat organizacji sejmów w Grodnie nie może być z perspektywy czasu pozytywna. Uwaga ta dotyczy szczególnie wyboru miasta, które było kompletnie nieprzygotowane do pełnienia tak ważnej funkcji. Brakowało kwater, ceny za gospody osiągały niebotyczny poziom. Do kłopotów przyczynili się sami Litwini, nie realizując własnych obietnic, w których gwarantowali, iż każdy powiat Wielkiego Księstwa wybuduje w Grodnie dom poselski. Połowiczne efekty przyniósł też remont zrujnowanego zamku grodzieńskiego, gdyż już po kilku latach od inwestycji jego stan był ponownie bardzo zły i budynek wymagał kolejnych napraw ${ }^{14}$. Mimo tak poważnych trudności w czasach Jana III sejmy w Grodnie organizowano trzykrotnie w latach 1678, 1688 i 1692-1693.

Drugą przyczyną zmian w zapisach prawnych związanych z kwestiami proceduralno-regulaminowymi była chęć poprawienia funkcjonowania instytucji sejmu. Proponowano $\mathrm{w}$ tym celu wiele rozwiązań prawnych. Jedno z nich dotyczyło wprowadzenia przysięgi, która obowiązywałaby wszystkich posłów sejmowych. Ponieważ postulat był forsowany przez opozycję, dwór starał się nie dopuścić do jego uchwalenia. Kilkuletnie spory zakończyły się wprowadzeniem w 1679 roku kompromisowego rozwiązania, na mocy którego zdecydowano, że przysięgę składać będą jedynie marszałek sejmu oraz deputaci do konstytucji ${ }^{15}$. Miało to być remedium na nadużycia i fałszerstwa, do jakich dochodziło po sejmie podczas przygotowywania (,ucierania”) ostatecznych tekstów uchwalonych praw przed oddaniem ich do ksiąg grodzkich warszawskich. Kompromis nie zadowolił szlachty, która działając na podstawie

11 Zmiany te zostały już częściowo zasygnalizowane w innym miejscu, zob. R. Kołodziej, Specyfika funkcjonowania sejmu Rzeczypospolitej w czasach Jana III Sobieskiego [w:] Między barokiem a oświeceniem..., s. 28-34.

12 R. Kołodziej, Litewski sejmik generalny w Stonimiu na tle sytuacji w Rzeczypospolitej przed sejmem 1685 roku, „Res Historica” 2015, nr 40, s. 97-113.

13 Utwierdzenie seymu grodzińskiego, VL, t. 5, s. 707.

14 Warunki sejmowania w Grodnie zob. R. Kołodziej, Ostatni wolności naszej klejnot. Sejm Rzeczypospolitej za panowania Jana III Sobieskiego, Poznań 2014, s. 104-115, 118-121.

15 Iurament Urodzonego Marszałka Poselskiego y Urodzonych Deputatów do Konstytucyi, VL, t. V, s. 546-547; dyskusję towarzyszącą wprowadzeniu konstytucji omawia K. Matwijowski, Sejm grodzieński 1678-1679, Wrocław 1985, s. 72-75, 97-98. 
precedensów, wprowadzała obowiązek przysięgi poselskiej na sejmikach ${ }^{16}$. Roty przysiąg z poszczególnych województw były do siebie podobne, posłowie mieli kierować się na sejmie dobrem publicznym, mieć przed oczyma wolność i nie brać udziału w „korupcjach” i „praktykach”. Prawo, choć skrupulatnie przestrzegane, nie poprawiło w żaden sposób jakości sejmowania, stając się szybko jedynie kolejnym elementem ceremonialnym.

Inicjatywa szlachty nie ograniczała się jedynie do samej przysięgi. W omawianym czasie próbowano wprowadzać również inne rozwiązania proceduralne, które miały usprawnić funkcjonowanie sejmu. Można do nich zaliczyć między innymi konstytucję zabraniającą posłom prolongowania obrad i posiedzeń przy świecach wprowadzoną w 1679 roku $^{17}$. Zakaz nocnych obrad był wcześniej obowiązującym zwyczajem parlamentarnym, lecz jego przestrzeganie pozostawiało wiele do życzenia. Ponieważ sesje podczas pierwszych sejmów w czasach Jana III ciągnęły się do późnych godzin nocnych, zdecydowano się spisać prawo potwierdzające wcześniejszy zwyczaj. Jednak jego egzekwowanie było nadal mocno dyskusyjne, a każdy dodatkowy dzień spędzony na sejmowaniu podczas coraz częściej prolongowanych obrad powodował, że niechęć posłów do nocnych posiedzeń pod koniec sejmu wyraźnie malała ${ }^{18}$. Paradoksalnie, zakaz obrad przy świecach nie sprawił, że posłowie zaprzestali nocnych posiedzeń, ale coraz częściej toczyły się one w półmroku lub w całkowitej ciemności, aby zadośćuczynić literze prawa. Do groteskowej sytuacji doszło w 1681 roku, kiedy to część posłów próbowała protestować przeciw wniesieniu świec na ceremonię żegnania króla, i to w momencie, gdy sejm uznano za zerwany ${ }^{19}$. Ostatecznie prawo to, które w zamyśle szlachty miało poprawić sprawność i transparentność obrad, bez wprowadzenia innych regulacji dotyczących na przykład sztywnych godzin funkcjonowania izby (a przede wszystkim wczesnego rozpoczynania posiedzeń) nie mogło odegrać konstruktywnej roli. Kolejne dwie konstytucje dotyczące procedury sejmowej uchwalono na sejmie 1690 roku. Pierwsza $\mathrm{z}$ nich regulowała porządek obrad sejmowych, druga proces oddawania konstytucji do druku ${ }^{20}$. Geneza pierwszej z nich była związana z ogromnym szokiem, jaki dla opinii publicznej stanowiło rozejście się sejmu 1688 roku bez wybrania marszałka.

16 Zob. R. Kołodziej, Ostatni wolności..., s. 354-356; tego typu rozwiązania stosowano incydentalnie już w czasach Jana Kazimierza, zob. M. Ujma, Sejmik lubelski 1572-1696, Warszawa 2003, s. 41; Z. Trawicka, Sejmik województwa sandomierskiego w latach 1572-1695, Kielce 1985, s. 37.

17 O Seymach deklaracya, VL, t. V, s. 547.

18 R. Kołodziej, Ostatni wolności..., s. 99-101; warto zauważyć, że wszystkie sejmy z omawianego okresu, które kończyły się uchwaleniem konstytucji, konkludowano późno w nocy lub nad ranem po całonocnym posiedzeniu.

19 „Więc gdy już nulla spes pożądanej obrady i effectius tego sejmu sperandus, ruszył się jm. pan marszałek poselski do thronu na pożegnanie Króla JM, ale że immediate po północy było, krzyknęli wszyscy panowie posłowie a prawie cała senatorska izba, aby po chrześcijańsku, a nie po pogańsku (bo bez świec siedzieli tak długo w noc) przy świecach pożegnali Króla JM”, zob. Diariusz seymu walnego zaczynającego się w Warszawie dnia 14 ianuarii roku pańskiego 1681, Archiwum Główne Akt Dawnych [dalej: AGAD], Archiwum Publiczne Potockich [dalej: APP], 323, s. 80.

20 Obiaśnienie konstytucyi dawnieyszych o porządku Seymowania; O dawaniu konstytucyi do druku, VL, t. V, s. 762-763. 
Z tego powodu uznano za konieczne spisanie kolejnych czynności, jakie powinna podejmować izba. Konstytucja to z pewnością krok w dobrym kierunku, lecz nadrzędność prawa do weta sprawiała, że przystąpienie do każdej czynności proceduralnej i regulaminowej można było oprotestować i nie dopuścić do kontynuowania obrad ${ }^{21}$. Źródłem drugiej konstytucji były ciągłe oskarżenia szlachty o nadużycia, do jakich dochodziło podczas redagowania uchwał sejmowych po zakończeniu obrad. Nie znalazła ona jednak zastosowania w czasach Jana III, gdyż wszystkie kolejne sejmy do śmierci króla zostały zerwane.

Analizując źródła historyczne przedstawiające sejmy z omawianej epoki, nie można oprzeć się wrażeniu, że zaprzątane były one coraz większą ilością zagadnień, z których przynajmniej część miała $\mathrm{w}$ istocie wartość jedynie ceremonialną. W mniejszym zakresie uwagę tę należy odnieść do uchwalonego w 1640 roku prawa nakazującego odczytywanie protokołów z rad senatu ${ }^{22}$. W czasach Sobieskiego było ono skrupulatnie przestrzegane, a szlachta uważała je za jedną z najważniejszych czynności inaugurujących obrady. Gdy jesienią 1678 roku król zaapelował do sejmików, aby podczas nadchodzącego sejmu zająć się w pierwszej kolejności sprawami państwowymi, szlachta wielkopolska w instrukcji nakazała posłom na początku obrad wysłuchać senatus consulta ${ }^{23}$. Czynność ta zajmowała przynajmniej kilka godzin, najdłużej trwała zapewne na sejmie $\mathrm{z}$ lat $1688-1689^{24}$. O ile prawo to można uznać za ważny element kontroli nad poczynaniami króla, o tyle trudno zgodzić się, aby takowym były odczytywane na każdym sejmie pacta conventa, który to tekst można było znaleźć w każdej kancelarii grodzkiej. Obowiązek ten wprowadzono w 1669 $\mathrm{roku}^{25}$, w konkretnej sytuacji politycznej związanej z abdykacją Jana Kazimierza. W kolejnych latach dla szlachty stało się ono jednym z najistotniejszych elementów procedury, a w instrukcjach sejmikowych nakazywano posłom bezwzględne jego przestrzeganie ${ }^{26}$. Nie mniej ważny był obowiązek upomnienia się o wakanse. Samo ich spisanie i ceremonialne wręczenie królowi pochłaniało wiele godzin, a nawet dni obrad. Oczekując na królewskie nominacje, izba mogłaby wprawdzie normalnie

21 „Tak więc konieczność bezwzględnego respektowania wolnego głosu i sprzeciwu sprawiała nieprzezwyciężone trudności zarówno przy uchwalaniu, jak i przestrzeganiu regulaminu”, zob. S. Ochmann-Staniszewska, Z. Staniszewski, op. cit., s. 83.

22 W. Czapliński, Walka pierwszych Wazów polskich ze stanami [w:] Studia z dziejów ustroju i skarbowości Rzeczypospolitej w XVII i XVIII w., red. K. Matwijowski, „Acta Universitatis Wratislaviensis", No 504, Historia 34, Wrocław 1981, s. 7-30.

23 Instrukcja Jana III na sejmik przedsejmowy województw poznańskiego i kaliskiego - Żółkiew, 3 X 1678, Archiwum Państwowe [dalej: AP] Toruń, Akta miasta Torunia, XIV 39, k. 7-10v; Instrukcja sejmiku województw poznańskiego i kaliskiego w Środzie, 3 XI 1678, AP Poznań, Księgi grodzkie [dalej: Ks. gr.] wschowskie, 178, k. 138v.

${ }^{24}$ Ze względu na zerwanie sejmu w 1688 r. przed odczytaniem, „senatu consulta”, 30 grudnia $1688 \mathrm{r}$. kanonik Boglewski, regent pieczęci koronnej, musiał odczytać aż dwadzieścia protokołów z lat 1685 1688 r., zob. [Diariusz sejmu 1688-1689], Geheimes Staatsarchiv Preussischer Kulturbesitz Berlin-Dahlem [dalej: GStPK], I HA, Rep. 9, 27.m.2, k. 8.

25 O początku Seymu, VL, t. V, s. 15.

26 Tak było choćby na sejmiku średzkim: „warowała sobie Rpta, aby pacta conventa na początku sejmu od krzesła JKM PNM suo ordine wszystkie czytane były, co aby i teraz conservatum było", zob. Instrukcja sejmiku średzkiego, 5 I 1685, AP Poznań, Ks. gr. poznańskie, 775, 178, k. 50v. 
pracować, jednak bywało, iż część posłów, stojąc na stanowisku, że wakanse powinny zostać rozdane na początku sejmu, nie chciała przystąpić do obrad. Tak było w 1683 roku, gdy izba zajęła się wakansami 30 stycznia, a następnie czekała na ich rozdanie aż do 8 lutego ${ }^{27}$. Często zdarzało się, że sprawa wakansów stawała się elementem walki politycznej. Kilkakrotnie atakowano królewskiego zaufanego Stanisława Antoniego Szczukę, zarzucając mu kumulację urzędów regenta kancelarii i referendarza ${ }^{28}$. W 1693 roku domagano się, aby uznać za wakans strażnikostwo koronne zajmowane przez innego królewskiego zaufanego, Stefana Bidzińskiego, który już wówczas sprawował urząd kasztelana sandomierskiego ${ }^{29}$. Tego typu wypadki oczywiście sprzyjały sporom i wydłużaniu czasu dyskusji o wakansach. W trakcie sejmów z omawianego okresu posłowie zajmowali się w izbie także spisywaniem egzorbitancji, które ceremonialnie przekazywano królowi, czekając na jego odpowiedź. Czynność ta wywoływała wśród parlamentarzystów niemałe spory i pochłaniała cenny czas. Na sejmie 1683 roku toczono zacięte debaty nad listą egzorbitancji, która ostatecznie w ogóle nie powstała ${ }^{30}$. Wreszcie obowiązkiem izby było wysłuchanie uchwalonych na poprzednim sejmie scripta ad archivum, które miało nastąpić bezpośrednio po propozycji od tronu. Przed tą czynnością należało jednak wyprosić z Senatu wszystkich arbitrów. Również bez obecności arbitrów odbywały się relacje dyplomatów, które czasem trwały kilka dni ${ }^{31}$.

Coraz bardziej rozbudowany ceremoniał obrad sejmowych widać też w innych elementach procedury. Jedną z nich były wygłaszane przy każdej okazji mowy. O skali i popularności zjawiska może świadczyć choćby to, że zachowane do dziś rozliczne sylwa szlacheckie obfitują w odpisy mów z czasów Jana III. Wówczas to pojawiły się na masową skalę pisane podręczniki oratorskie, w których znajdowały się ponadto okolicznościowe mowy dla marszałka poselskiego. Każdą bowiem okazję i każdy element procedury należało rozpocząć i spuentować odpowiednią mową. Do szczególnie interesujących wzorów mów można zaliczyć - charakterystyczne dla omawianych czasów i zachowane w wielu sylwach - mowę dziękującą posłowi za przywrócenie izbie activitatis czy mowę żegnającą króla po zerwanym sejmie ${ }^{32}$. Wszystkie te czynności ceremonialne były dla szlachty niezwykle ważne, a sztukę oratorską ceniono bardzo wysoko.

Z pewnością jednak cechą wyróżniającą sejmy z czasów Jana III na tle innych była ich długość trwania. Zgodnie z prawem czas sejmowania ograniczony był do sześciu tygodni, tymczasem w omawianym okresie ciągnął się często ponad trzy,

27 Diariusz sejmu walnego sześćniedzielnego warszawskiego anno 1683 die 27 ianuarii zaczętego, AGAD, APP 324, s. 4-14.

${ }_{28}$ R. Kołodziej, Ostatni wolności..., s. 40.

29 Sejm walny sześćniedzielny grodzieński sub auspiciis najjaśniejszego KJM Jana III za dyrekcyjej izby poselskiej wielmożnego jm. pana Kryszpina pisarza polnego W. Ks. Lit. w roku 1692 die 31 decembris zaczęty, AGAD, Archiwum Radziwiłłów, dz. VI, II-51, s. 9.

30 R. Kołodziej, Ostatni wolności..., s. 211.

31 W pacta conventa Jana III zapisano konieczność składania relacji z poselstw na sejmach, zob. VL, t. V, s. 266-267.

32 Przykładowe mowy marszałka Tomasza Działyńskiego zob. Biblioteka Narodowa [dalej: BN], Biblioteka Ordynacji Zamoyskich [dalej: BOZ], 1150, k. 3-8v; BN, III.6641, k. 36-39v. 
a nawet cztery miesiące ${ }^{33}$. Powody tego zjawiska były przeróżne. Wiązały się zarówno ze wspomnianym wyżej rozrostem ceremoniału, coraz większym zakresem obowiązków poselskich, ale i z coraz częstszym wykorzystywaniem zasady wolnego głosu do walki politycznej i obstrukcji obrad. Na pewno obniżała się kultura polityczna szlachty i spadała świadomość odpowiedzialności za losy własnego kraju. Lektura korespondencji z epoki skłania do opinii, że sejm traktowano nierzadko jako miejsce załatwiania interesów partykularnych lub osobistych, dlatego poszczególne partie potrafiły przez wiele tygodni stosować obstrukcję parlamentarną, aby zmusić przeciwnika do ustępstw. Najczęściej protestujący powoływali się przy tym na dobro publiczne, choć bardzo często był to jedynie pretekst. Sejmy z lat 1677 i 1678-1679 zwłóczono na kwestii przysięgi poselskiej ${ }^{34}$. W 1685 roku część Litwinów przez kilka tygodni nie chciała rozpocząć sejmowania w Warszawie i domagała się przeniesienia obrad do Grodna ${ }^{35}$. W 1688 roku kilka tygodni trwały przepychanki wokół próby wyrugowania z izby Kazimierza Dąbrowskiego, sapieżyńskiego partyzanta, czego skutkiem było zakończenie obrad przed obiorem marszałka ${ }^{36}$. Wybuchające raz po raz w izbie kolejne konflikty i zacietrzewienie obu stron, przejawiające się w blokowaniu activitatis, odbijało się negatywnie na sprawności i czasie trwania obrad. Niosło to za sobą interesujące konsekwencje - posłowie, chcąc przyspieszyć ciągnące się miesiącami sejmy, zaczęli sami rezygnować z niektórych elementów procedury ${ }^{37}$. Ciężar głównych obrad przenosił się z izby poselskiej do Senatu, ponieważ podczas pierwszych pięciu tygodni sejmowania posłom rzadko zdarzało się uzgodnić jakiekolwiek projekty. Co więcej, posłowie litewscy sprawy Wielkiego Księstwa przenosili na forum swoich sesji prowincjonalnych, gdzie przez wiele tygodni procedowali projekty konstytucji litewskich, które następnie odczytywali na forum Senatu. Można więc zauważyć, że wewnątrz sejmu Rzeczypospolitej wykształcił się swoisty „wewnętrzny” sejm litewski. Zdarzało się, że Litwini całymi tygodniami obradowali jedynie na swoich sesjach, jak w 1681 roku, gdy począwszy od pierwszego tygodnia marca, niemal codziennie spotykali się w klasztorze Jezuitów i tylko z rzadka, co kilka dni pojawiali się w Senacie ${ }^{38}$. Autor diariusza sejmowego z 1677 roku pod datą 31 marca zapisał, że „panowie litewscy przez niedziel trzy nie bywali w senacie, po prywatnych ułatwiwszy sobie wszystkie materyje sesyjach"39. Opinie na temat tych praktyk były różne, choć ówcześni obserwatorzy dostrzegali pożyteczną stronę sesji, podczas których można było łatwiej uzgodnić poszczególne projekty. Sesje

33 R. Kołodziej, Specyfika funkcjonowania..., s. 31-32.

34 Kwestie te szeroko omówił K. Matwijowski, Pierwsze sejmy z czasów Jana III Sobieskiego, Wrocław 1976, s. 198-199, 218 passim; idem, Sejm grodzieński..., s. 72-75.

35 Zob. R. Kołodziej, Litewski sejmik..., s. 110.

36 Szeroko na ten temat J. Maroń, Sejmy z lat 1688-1689, mps pracy doktorskiej, Biblioteka IH UWr.

37 W 1685 r. zrezygnowano z części wotów senatorskich, okazało się bowiem, że przed ich zakończeniem upłynął termin sześciu tygodni, zob. Journal des polnischen Reichstags de anno 1685, GStPK, I HA, Rep. 9, 27.k.3, k. 28-32; R. Kołodziej, Ostatni wolności..., s. 217, 221 tab. 11.

38 Jan Antonii Chrapowicki, Pamiętnik, Muzeum Narodowe Kraków, 169, t. 6, s. 100-139.

39 Diariusz sejmu koronnego die 14 ianuarii 1677ma w Warszawie zaczętego, Biblioteka Zakładu Narodowego im. Ossolińskich [dalej: BOss], 247, k. 533v. 
prowincji organizowali również Wielko- i Małopolanie, ale ich posiedzenia były zazwyczaj jednodniowe i miały na celu jedynie uzgodnienie stanowisk, bez spisywania projektów konstytucji.

Prolongowanie obrad niosło za sobą przede wszystkim konsekwencje negatywne. Potencjalny zrywacz otrzymywał bowiem do ręki argument nie do podważenia, gdyż każda prolongata zależała od konsensusu izby. Obserwując wydłużające się w nieskończoność obrady, warto docenić również determinację posłów, którzy przez kilka miesięcy cierpliwie przebywali w mieście sejmowym, chcąc doprowadzić do szczęśliwego ich zakończenia ${ }^{40}$. A przedłużające się sejmy to znaczny wzrost kosztów utrzymania. $Z$ tego powodu w omawianym czasie sejmiki coraz częściej decydowały się na wypłatę diet poselskich ${ }^{41}$. Kwoty te były oczywiście niewystarczające, a to prowadziło do korupcji. Na listach wypłat zachowanych w archiwach w Berlinie, Paryżu czy Wiedniu można znaleźć nazwiska bardzo wielu senatorów i posłów ${ }^{42}$. Większość z nich brała zresztą pieniądze od każdego, kto był skłonny je dać. W procesie korumpowania posłów niemałą rolę odgrywali także senatorowie, ale i dwór królewski, mający do dyspozycji pieniądze, urzędy i królewszczyzny. Warto natomiast zauważyć, że mimo powszechnego łapownictwa było ono surowo potępiane, a oskarżenia, że ktoś wziął pieniądze od obcych rezydentów, wywoływały oburzenie.

Z pewnością w czasach Jana III można zauważyć dalsze utrwalanie się zasady liberum veto ${ }^{43}$. Nie była ona kwestionowana jako prawo, choć czasem pojawiał się w dyskursie publicznym postulat jej tzw. opisania. W wygłoszonych na sejmie 1688 roku mowach Stanisław Dunin Karwicki opowiadał się przeciw prawu do protestu wobec czynności sejmowych, uważając, że zasada jednomyślności powinna obowiązywać jedynie w przypadku uchwalania konkretnych praw ${ }^{44}$. Tego typu głosy były jednak rzadkie, a w powszechnej opinii prawo do wolnego głosu było jedną z najważniejszych i niekwestionowanych szlacheckich prerogatyw. Należy jednak przy tym zauważyć, że szansa na złożenie skutecznego protestu przez posła w trakcie trwania sejmu nie w każdym przypadku była taka sama. Pojedynczy parlamentarzysta,

40 Coraz częściej zdarzało się, że część posłów z jednego sejmiku, zapewne z przyczyn materialnych, rozjeżdżała się do domów, pozostawiając na miejscu swego reprezentanta, zob. R. Kołodziej, Ilu postów brało udział w obradach sejmowych w czasach Jana III Sobieskiego? [w:] Spoleczeństwa Europy Środkowo-Wschodniej w epoce wczesnonowożytnej, red. J. Maroń, F. Wolański, L. Ziątkowski, Wrocław 2016, s. 61-62.

${ }^{41}$ Kwestię diet poselskich zob. A. Filipczak-Kocur, Kto wyptacat diety poselskie w XVII w.? [w:] Parlament, prawo, ludzie. Studia ofiarowane Profesorowi Juliuszowi Bardachowi w sześćdziesięciolecie pracy twórczej, red. K. Iwanicka, M. Skowronek, K. Stembrowicz, Warszawa 1966, s. 68-73.

42 Morale posłów scharakteryzowano w S. Ochmann-Staniszewska, Z. Staniszewski, op. cit., s. 57-61; liczne przykłady korupcji stosowanej przez dyplomatów brandenburskich podaje A. Ka mieński, Polska a Brandenburgia-Prusy $w$ drugiej potowie XVII wieku. Dzieje polityczne, Poznań 2002, passim.

43 W. Konopczyński, Liberum veto. Studium porównawczo-historyczne, Kraków 2002 (wyd. 2), s. 243-246, 248-268; ostatnio na ten temat zob. R. Kołodziej, Prawo do protestu w praktyce sejmowej i sejmikowej w czasach Jana III Sobieskiego, „Biblioteka Epoki Nowożytnej” 2016, nr 4, s. 71-96.

44 Mowa Stanisława Dunin Karwickiego na sejmie grodzieńskim miana 1688 r., B. Polskiej Akademii Umięjętności i Polskiej Akademii Nauk Kraków [dalej: B PAU i PAN], 671, s. 84; Mowa Stanisława Dunin Karwickiego [w:] Źródła do dziejów Polski, wyd. F. Nowakowski, t. 2, Berlin 1841, s. 380-386. 
pozbawiony politycznego zaplecza i wsparcia innych osób, mógł łatwo zostać zakrzyczany, a nawet zmuszony do ucieczki z koła. Na skuteczny protest mogła sobie pozwolić „partia” złożona z grupy posłów, a często i ze wsparciem senatorów. Zresztą większość protestów składanych w izbie miała charakter taktyczny, a ich celem nie było zerwanie obrad. Nie znaczy to, że zasada jednomyślności nie odcisnęła swojego piętna na sejmach w omawianym okresie - na dwanaście zwołanych zjazdów w latach 1676-1695 zerwano sześć, ale aż pięć od 1688 roku. Można to zapewne powiązać między innymi ze wzrostem siły stronnictw opozycyjnych wobec dworu (związanych z potężnymi Sapiehami), jak i z pogarszającą się kondycją zdrowotną króla, który miał coraz mniej energii na działalność polityczną. Dowodziłoby to jednak, że rola monarchy w skuteczności sejmowania była nie do przecenienia.

Szlachta zdawała sobie sprawę z pogłębiającego się kryzysu systemu parlamentarnego, dlatego na sejmikach proponowano pewne jego reformy ${ }^{45}$. Ich ograniczony zakres wynikał jednak z obawy przed nieprzewidzianymi następstwami zbyt gwałtownych zmian. Dlatego nawet gdy szlacheccy obywatele nakazywali swoim posłom debatę nad reformą konkludowania sejmów, to zawsze z zastrzeżeniem, aby nie naruszało to zasady wolnego głosu. Ciężki niedowład sejmowy w ostatnich latach rządów Jana III zaowocował natomiast hasłami radykalnymi, wśród których na czoło wybijał się postulat zwołania sejmu konnego, mającego rozprawić się z wrogami Rzeczypospolitej, a przywracając dawne cnoty i zwyczaje, uzdrowić również instytucję sejmu ${ }^{46}$. Zdaniem szlachty kryzys wynikał więc z powodu upadku obyczajów, a nie obowiązujących rozwiązań prawnoustrojowych. Takie przekonanie nie dawało większych nadziei na reformy, tym bardziej że nie widać zaangażowania króla w promowanie konkretnych zmian. W oficjalnych dokumentach przedsejmowych takich projektów brak, nieliczne pisma polityczne powstałe z inicjatywy dworu miały chyba niewielki oddźwięk i nie odegrały większej roli opiniotwórczej w społeczeństwie szlacheckim ${ }^{47}$.

Omawiany okres jest niezwykle istotny z punktu widzenia funkcjonowania sejmików szlacheckich i doczekał się nawet terminu „sejmikokracja”. Już w pierwszej połowie XVII wieku rozpoczął się proces przekazywania sejmikom kompetencji będących wcześniej w gestii sejmu. Było to związane na pewno z rosnącą nieufnością szlachty co do funkcjonowania urzędów centralnych i chęcią objęcia większą

45 Szczegółowo omówiono je w: R. Kołodziej, Poprawa funkcjonowania sejmu w opinii szlachty w czasach Jana III Sobieskiego [w:] Szlachta polska i jej dziedzictwo. Księga na 65 lat Prof. dr. hab. Jana Dzięgielewskiego, Warszawa 2013, s. 229-238.

46 H. Olszewski, Sejm konny. Rzecz o funkcjonowaniu ideologii demokracji szlacheckiej w dawnej Polsce, „Czasopismo Prawno-Historyczne” [dalej: CPH] 1985, nr 37, z. 2, s. 225-242; sejmik sandomierski, stając w obronie monarchy, samorzutnie chciał organizować wyprawę na Litwę skierowaną przeciwko stronnikom Sapiehów, zob. K. Piwarski, Projekty reformy państwa za Jana III Sobieskiego [w:] Studia historyczne ku czci Stanisława Kutrzeby, t. 1, Kraków 1938, s. 368.

47 Propozycje gruntownych zmian w procedurze sejmowej omówiono w: R. Kołodziej, Reforma procedury sejmowej $w$ świetle anonimowej polemiki przed sejmem $1683 r$. [w:] Sic erat in fatis. Studia i szkice historyczne dedykowane Profesorowi Bogdanowi Rokowi, t. 2, Toruń 2012, s. 152-162; tam też przegląd literatury na ten temat, zob. s. 155, przyp. 11. 
kontrolą przede wszystkim spraw skarbowych i podatkowych ${ }^{48}$. Od połowy XVII wieku w uchwalanych na sejmie deklaracjach podatkowych posłowie decydowali jedynie o wysokości ciężarów przypadających na ich ziemię, pozostałe kwestie przenosząc na sejmiki. Należały do nich decyzje na temat rodzajów wybieranych podatków, taryf i kalendarza podatkowego. Sejmik wybierał poborców, ustalał ich wynagrodzenie, decydował o terminie wydawania zebranych sum. W jego gestii znajdował się wybór członków sądów skarbowych, którzy mieli oceniać prawidłowość wybierania podatków i rozliczać poborców ${ }^{49}$. Sejmik mógł przyznawać zwolnienia i ulgi podatkowe. Wreszcie od jego decyzji zależała dystrybucja zebranych sum. Ponieważ $\mathrm{w}$ omawianym okresie funkcjonowała zasada repartycji, czyli przypisania poszczególnych jednostek wojska do konkretnych ziem ${ }^{50}$, w których przedstawiciele armii mieli odbierać żołd, w kompetencje sejmiku weszły również kwestie bezpośrednio związane z funkcjonowaniem armii. Sejmiki kontaktowały się z przedstawicielami chorągwi i regimentów, przybywającymi do ziem w celu odebrania należnych im sum. Pieniędzy najczęściej nie udawało się zebrać w przewidzianym terminie, dlatego też niejednokrotnie posłowie wojskowi miesiącami rezydowali w poszczególnych ziemiach, oczekując na wypłacenie żołdu.

Wzrost znaczenia sejmików wynikał po części z coraz gorszego funkcjonowania sejmu. Choć początkowo szlachta z poszczególnych ziem broniła się przed samodzielnymi decyzjami w sprawach podatkowych, to pod koniec panowania Jana III niektóre zjazdy szlacheckie zaczęły samodzielnie uchwalać podatki, gdy kolejne sejmy były zrywane ${ }^{51}$. Te precedensy powstałe $\mathrm{w}$ omawianych czasach zostaną $\mathrm{w}$ przyszłości rozwinięte i pozwolą szlachcie oprzeć funkcjonowanie państwa na rządach sejmikowych w okresie wielkiej wojny północnej, kiedy sejmy przez wiele lat nie były w ogóle zwoływane.

Wzrost znaczenia sejmików i rosnące kompetencje sprawiały, że obradowały one coraz częściej. Oczywiście szlachta nie mogła samodzielnie zwoływać sejmików, a prerogatywa ta należała w czasach regnum do monarchy (w niektórych przypadkach do wojewodów). Konieczność częstego zjeżdżania się wymagała każdorazowo uzyskania nowego uniwersału królewskiego, a to wiązało się z kosztami wynikającymi z wyprawienia do monarchy odpowiedniego poselstwa. Szlachta znalazła więc

48 Zob. M. Nycz, Geneza reform skarbowych sejmu niemego. Studium z dziejów skarbowo-wojskowych z lat 1697-1717, Oświęcim 2016, s. 101.

49 W prowincji wielkopolskiej doszło z tego powodu do wykształcenia się w $1685 \mathrm{r}$. stałego organu kontroli skarbowej - Komisji Skarbowej Poznańskiej, zob. M. Zwierzykowski, Komisja Skarbowa Poznańska. Z dziejów sejmikowej administracji i sądownictwa skarbowego w Wielkopolsce w XVII i XVIII w. Poznań 2003.

50 Zasadę wprowadzono po raz pierwszy konstytucją z 1652 r., zob. Obrona, Volumina Constitutionum, t. 4, vol. 1, s. 257. W czasach Jana III dokonano nowej repartycji skryptem do archiwum z sejmu 1690 r., zob. Lokacya wojska y skryptu ad archivum danego approbacya, VL, t. 5, s. 765-766; Skrypt ad archivum dany na sejmie walnym warszawskim 1690, Biblioteka XX. Czartoryskich w Krakowie [dalej: B. Czart.], Teka Naruszewicza [dalej: TN] 183, s. 297-300.

51 Jednym z pierwszych sejmików, który podjął decyzje podatkowe po zerwanym sejmie, był egzulancki sejmik kijowski, który w 1681 r. uchwalił podwójne podymne, zob. Instrukcja do JKM posłom województwa kijowskiego, 15 VII 1681, AGAD, APP, 133, s. 110-111. 
wyjście z sytuacji, aby sejmikować częściej, omijając jednocześnie królewską prerogatywę. Sposobem obejścia prawa stała się zasada limity, to znaczy wielokrotnego zjeżdżania się na podstawie jednego uniwersału ${ }^{52}$. Warunkiem limity było oczywiście podjęcie przez sejmik odpowiedniej uchwały i zachowanie ciągłości władzy marszałka sejmikowego, choć w tym drugim przypadku istnieją wyjątki ${ }^{53}$. Limita, której pierwsze przykłady można znaleźć w schyłkowym okresie rządów Jana Kazimierza, na masową skalę zaczęła funkcjonować właśnie w czasach Jana III Sobieskiego. Przyczyny odkładania obrad podawane w laudach przez szlachtę były przeróżne. Często stanowiły efekt opieszałej pracy kancelarii królewskiej, która nie potrafiła odpowiednio szybko rozesłać po ziemiach konstytucji sejmowych. Zgromadzona na sejmiku szlachta bez drukowanych konstytucji nie chciała podejmować jakichkolwiek czynności podatkowych. Zdarzało się też, że na sejmik relacyjny nie przybyli posłowie sejmowi albo frekwencja szlachty była zbyt niska ${ }^{54}$. Wreszcie bardzo często natłok spraw do załatwienia był tak duży, że sejmik część z nich przenosił na następny zjazd. Odkładano wówczas obrady o kilka tygodni, a z czasem zaczęto tworzyć cały łańcuch limit, który mógł ciągnąć się ponad rok. Nierzadko limity prowadziły do znacznych opóźnień w zbieraniu i wydawaniu podatków, ponieważ sejmiki przekładały decyzje na czas późniejszy. Cierpiało na tym wojsko, które nie otrzymywało wynagrodzenia na czas.

Ówczesne sejmiki nie były wolne od ostrej walki politycznej. Jej rezultat to coraz częstsze zrywanie szlacheckich zjazdów, również tych najważniejszych. Sejmik województw poznańskiego i kaliskiego w czasach Jana III nie miał swojej reprezentacji na trzech sejmach, podobnie zresztą jak sejmik województwa krakowskiego. Ratunkiem dla coraz częściej rwanych zjazdów przedsejmowych okazywały się sejmiki powtórne, co także było cechą charakterystyczną sejmikowania ostatnich trzydziestu lat XVII wieku. Był to ponadto sposób na przechytrzenie opozycji i „kradzież” sejmiku. Niedwuznaczne zarzuty tego typu stawiał zagorzały opozycjonista Jan Chryzostom Pieniążek, wojewoda sieradzki - w liście do Jana III przed sejmem 1688 roku pisał, iż powtórny uniwersał króla na sejmik sieradzki jest w posiadaniu Melchiora Grudzińskiego, kasztelana sieradzkiego, który go „pod znakiem woli i dyskrecyjej swojej trzyma". Wojewoda nie omieszkał wspomnieć, że uniwersał powinien trafić do grodu, a nie do rąk kasztelana ${ }^{55}$.

52 Jako jeden z pierwszych na ten proceder uwagę zwrócił H. Olszewski, Praktyka limitowania sejmików, CPH 1961, nr 13, z. 1, s. 33-55.

53 Na przykład sejmik relacyjny bełski w $1681 \mathrm{r}$. dwukrotnie zalimitował obrady i dwukrotnie zmieniał osobę marszałka, zob. Laudum sejmiku bełskiego z 15 VII 1681 r., Centralnyj Dierżawnyj Istorycznyj Archiw Ukrainy Lwów [dalej: CDIAUL], Fond 1, Opis 1, 274, s. 1621-1628 (marszałek Wojciech Alojzy Zieliński wojski buski); Laudum sejmiku z 17 IX 1681 r., CDIAUL, Fond 1, Opis 1, 274, s. 1915 1916 (marszałek Wojciech Kazimierz Koc podsędek ziemski buski); Laudum sejmiku bełskiego z 5 XI 1681 r., CDIAUL, Fond 1, Opis 1, 274, s. 2162-2164 (marszałek Michał Pajowski).

${ }_{54} \mathrm{Na}$ sejmik relacyjny sieradzki w 1677 r. nie dotarli obywatele powiatów piotrkowskiego i radomskiego, dlatego został on limitowany, zob. Laudum sejmiku sieradzkiego z 10 VI 1677 r., B PAU i PAN, 8343, s. 423-424.

55 Jan Chryzostom Pieniążek do Jana III, b.m. i d. [początek 1688 r.], BOss, 1767, s. 198-199. 
Rosnąca rola sejmików i kryzys sejmu prowadziły do postępującego wzrostu poczucia nadrzędności demokracji bezpośredniej nad przedstawicielską. Prawo wprawdzie nadal uchwalano na sejmie, ale niejednokrotnie szlachta na sejmikach kwestionowała część konstytucji, jeśli wysłani przez nią posłowie w swoich relacjach dowodzili, że zostały one przyjęte wbrew ich woli lub za ich niewiedzą. Zanoszono wówczas protestacje do grodów, wysyłano posłów do króla i deklarowano, że ziemia nie będzie podlegać nielegalnie uchwalonym prawom.

Dopełnieniem systemu parlamentarnego były rady senatu ${ }^{56}$. Pozostawały one integralnie związane z instytucją sejmu i sejmików. Decyzja rady senatu była niezbędna, aby król mógł zwołać sejm, wysyłając do nieobecnych członków rady deliberatoria. Rada podejmowała również inne decyzje, mające wpływ na sejmowanie. Mogła na przykład poradzić królowi odłożenie obrad sejmowych, jak w przypadku sejmu koronacyjnego, który odwleczono o ponad rok $^{57}$. Opierając się na decyzjach senatu, Jan III zwlekał ze składaniem sejmów w latach $1685-1688$ oraz $1690-1692^{58}$. Rady senatu mogły ponadto zmienić miejsce obrad sejmowych. Tak się stało w 1684 roku, kiedy na wniosek króla zdecydowano o wyjątkowym przeniesieniu sejmu z Grodna do Warszawy ${ }^{59}$.

Ważnym elementem systemu parlamentarnego były posejmowe rady senatu, szczególnie po sejmach zerwanych. Królowi zależało na tym, aby sejmiki posejmowe doszły do skutku i samodzielnie uchwaliły podatki, a decyzję na ten temat mogła podjąć właśnie rada ${ }^{60}$. Jedynym sejmem, po którym nie zwołano posejmowej rady senatu, był jednodniowy zjazd z 22 grudnia 1693 roku $^{61}$. Nie odbyły się też wówczas sejmiki relacyjne, jednak na podstawie decyzji rady senatu z początków marca 1694 roku król poinformował szlachtę specjalnymi uniwersałami o przyczynach niedojścia sejmu ${ }^{62}$.

56 Uwagi na temat senatu w czasach Jana III, zob. K. Matwijowski, Senat w czasach Jana III Sobieskiego [w:] Senat w Polsce. Dzieje i teraźniejszość, red. K. Matwijow ski, J. Pietrzak, Warszawa 1993, s. 117-124.

57 Sejm, zgodnie z pierwotnym założeniem, miał być zebrany na początku 1675 r., zob. Denuntiatio Regis coronati Ioannis III, VL, t. V, s. 329.

58 List Jana III do szlachty lubelskiej o odłożeniu sejmu za radą senatorów, Lwów, 4 II 1692, Lietuvos mokslų akademijos Vrublevskiu biblioteka, F. 20-1209, k. 4-7v.

59 Senatus consilium, Żółkiew, 6 VII 1684, AGAD, Archiwum Zamoyskich, 3046, s. 387; Senatus consilium, w obozie pod Niezborodami, 16-17 X 1684, ibidem, s. 414-415; Senatus consilium, b.m., 31 X 1684 r., ibidem, s. 415.

${ }^{60}$ „Żeby zaś po straconym sejmie pod rządem naszym Rpta bez obrony nie zostawała, nie folgując nic tak długiej pracy naszej, nec dato post tot exactas curas interstitio, rzuciliśmy się do walnej posejmowej rady, na której cokolwiek ad conservationem publicam et momenta rerum należało, z przytomnym senatem in frequentia zgromadzonych stanów tej R.P. adaequata media umówiliśmy", zob. Uniwersał Jana III zwołujący sejmik relacyjny w Środzie, Warszawa, 14 VI 1681, AP Poznań, Ks. gr. wschowskie, 179, k. 131.

${ }_{61}$ R. Kołodziej, Sejm z 22 grudnia 1693 roku, „Wieki Stare i Nowe” 2016, nr 10, s. 47-76. Król nie dojechał wówczas do Warszawy i posłowie rozjechali się do domów.

${ }_{62}$ Senatus consilium, b.m., 5 III 1694, B. Czart., rkps 866, s. 91; Uniwersał Jana III informujący szlachtę o niedojściu sejmu, AP Poznań, Gr. Poznań, 796, k. 103. 
Ponieważ Jan III z czasem był coraz bardziej zniechęcony do wydłużających się i męczących sejmów, można odnieść wrażenie, że rady senatu stanowiły dla niego wygodną alternatywę. Monarcha zwoływał je stosunkowo często - Jackowi Krupie udało się zebrać informacje na temat 74 posiedzeńn ${ }^{63}$, co już daje średnią między trzy a cztery spotkania rocznie. Rady odbywały się w miejscu pobytu króla, dlatego zwoływano je zwykle w ruskich majątkach Sobieskiego, gdzie przybywali najczęściej tylko zaufani senatorowie, a to dawało monarsze swobodę w kształtowaniu konkluzji. Zapewne dla króla najwygodniej byłoby w jakimś stopniu zastąpić sejmy radami. Przykładem takich działań było zwołanie wielkiej rady senatu w Warszawie w 1680 roku. Odbyła się ona na podstawie decyzji pierwszego sejmu grodzieńskiego, który dał w ręce Jana III i specjalnie wybranych deputatów prawo do negocjacji w sprawach tworzenia ligi przeciw Porcie ${ }^{64}$. Pomysł przez szlachtę został przyjęty sceptycznie, bo tego typu inicjatywę uznano za nowośćc ${ }^{65}$. Ostatecznie rada odbyła się na początku stycznia 1680 roku w Warszawie, jednak jej obrady okazały się bezowocne, co musiało utwierdzić króla w przekonaniu, że w przypadku najważniejszych spraw państwa bez sejmu nie będzie się mógł obejśćc6 ${ }^{66}$ Zgodnie z prawem po każdej radzie powstawał jej protokół, zawierający propozycje i konkluzję. Protokoły powinny być odczytywane w obecności posłów podczas obrad sejmowych. Ze względu na brak czasu nie zawsze element ten był jednak na sejmach realizowany. Na tle przeżywających coraz większy kryzys instytucji sejmu i sejmików rady senatu zdawały się elementem nad wyraz opornym na kryzys. Ale pozostałych instytucji nie mogły zastąpić ${ }^{67}$.

W systemie parlamentarnym doby Jana III z pewnością można wyróżnić dwa zasadnicze okresy, w których cezurą byłyby lata między sejmami 1685 i 1688 roku. Choć jednak w początkach rządów Sobieskiego sejmy najczęściej kończyły się uchwalaniem konstytucji, to widać spadającą efektywność obrad, zwiastującą przyszłe problemy. Poważny kryzys sejmu pod koniec panowania Sobieskiego sprawił, że ciężar decyzji państwowych musiał przenosić się na inne organa. Dla króla wygodniejsze byłyby z pewnością rady senatu, lecz dla szlachty takie rozwiązanie było nie do zaakceptowania. $Z$ tego też powodu można zaobserwować proces wzrostu kompetencji sejmików ziemskich, którego apogeum przypadnie na początek XVIII wieku, gdy szlachta z powodu wojny północnej przez długie lata będzie musiała radzić sobie bez sejmu.

63 J. Krupa, Rady senatu za Jana III Sobieskiego (1674-1696), „Studia Historyczne” 1992, nr 35, z. 3 , s. 309.

${ }^{64}$ Deputaci do boku naszego, VL, t. 5, s. 551-553.

${ }_{65}$ Protestowała m.in. szlachta wielkopolska, zob. Krzysztof Unrug starosta gnieźnieński do Joachima Scultetusa, Międzychód, 24 VI 1679, GStPK, I HA, Rep. 9, 27.e, Fasz. 3, k. 64-65.

${ }_{66}$ Konkluzja wielkiej rady warszawskiej, B. Czart., TN 181, s. 85-94.

${ }_{67}$ Zob. interesujące uwagi na ten temat: M. Markiewicz, Rzeczpospolita bez sejmu. Funkcjonowanie państwa [w:] Między barokiem a oświeceniem. Nowe spojrzenie na czasy saskie, red. K. Stasiewicz, S. Achremczyk, Olsztyn 1996, s. 175-180. 


\section{BIBLIOGRAFIA}

\section{Rękopisy}

Archiwum Główne Akt Dawnych

Archiwum Publiczne Potockich: 133, 323, 324.

Archiwum Radziwiłłów: dział VI, II-51.

Archiwum Zamoyskich: 3046.

Archiwum Państwowe w Poznaniu

Księgi grodzkie poznańskie: 775, 796.

Księgi grodzkie wschowskie: 178, 179.

Archiwum Państwowe w Toruniu

Akta miasta Torunia, XIV 39.

Biblioteka XX. Czartoryskich w Krakowie

Teki Naruszewicza 181, 183, rękopisy 866.

Biblioteka Narodowa w Warszawie

III.6641.

Biblioteka Ordynacji Zamoyskich

1150.

Biblioteka PAU i PAN w Krakowie

$671,8343$.

Biblioteka Zakładu Narodowego im. Ossolińskich we Wrocławiu 247, 1767.

Centralnyj Dierżawnyj Istorycznyj Archiw Ukrainy Lwów

Fond 1, Opis 1, 274.

Geheimes Staatsarchiv Preussischer Kulturbesitz Berlin-Dahlem

I HA, Rep. 9, 27.e Fasz. 3, 27.k.3, 27.m.2.

Lietuvos mokslų akademijos Vrublevskių biblioteka Wilno

F. 20-1209.

Muzeum Narodowe w Krakowie

169 , t. 6. 


\section{Źródła drukowane}

Volumina Constitutionum, t. 4, vol. 1, przyg. S. Grodziski, M. Kwiecień, K. Fokt, Warszawa 2015.

Volumina Legum, t. V, wyd. J. Ohryzko, Petersburg 1860.

Źródła do dziejów Polski, wyd. F. Nowakowski, t. 2, Berlin 1841.

\section{Literatura}

Bobiatyński K., Michat Kazimierz Pac-wojewoda wileński, hetman wielki litewski. Dziatalność polityczno-wojskowa, Warszawa 2008.

Bobiatyński K., W walce o hegemonię. Rywalizacja polityczna w Wielkim Księstwie Litewskim w latach 1667-1674, Warszawa 2016.

Czapliński W., Walka pierwszych Wazów polskich ze stanami [w:] Studia z dziejów ustroju i skarbowości Rzeczypospolitej w XVII i XVIII w., red. K. Matwijowski, „Acta Universitatis Wratislaviensis", No 504, Historia 34, Wrocław 1981.

Filipczak-Kocur A., Kto wyptacat diety poselskie w XVII w.? [w:] Parlament, prawo, ludzie. Studia ofiarowane Profesorowi Juliuszowi Bardachowi w sześćdziesięciolecie pracy twórczej, red. K. Iwanicka, M. Skowronek, K. Stembrowicz, Warszawa 1966.

Jaroszuk J., Radziwitt Michat Kazimierz h. Traby (1635-1680) [w:] Polski słownik biograficzny, t. 30, s. 293-299.

Kamieński A., Polska a Brandenburgia-Prusy w drugiej połowie XVII wieku. Dzieje polityczne, Poznań 2002.

Kamieński A., Wptywy polityczne Brandenburgii-Prus na sejmiku średzkim za panowania Jana III Sobieskiego [w:] Między barokiem a oświeceniem. Parlamentaryzm, red. B. Krysztopa-Czupryńska, J. Kiełbik, Olsztyn 2016.

Kawecki R., Kardynat Michat Stefan Radziejowski (1645-1705), Opole 2005.

Kołodziej R., Ilu postów brało udziat w obradach sejmowych w czasach Jana III Sobieskiego? [w:] Społeczeństwa Europy Środkowo-Wschodniej w epoce wczesnonowożytnej, red. J. Maroń, F. Wolański, L. Ziątkowski, Wrocław 2016.

Kołodziej R., Litewski sejmik generalny $w$ Stonimiu na tle sytuacji $w$ Rzeczypospolitej przed sejmem 1685 roku, „Res Historica” 2015, nr 40, s. 97-113.

Kołodziej R., Ostatni wolności naszej klejnot. Sejm Rzeczypospolitej za panowania Jana III Sobieskiego, Poznań 2014.

Kołodziej R., Poprawa funkcjonowania sejmu w opinii szlachty w czasach Jana III Sobieskiego [w:] Szlachta polska i jej dziedzictwo. Księga na 65 lat Prof. dr. hab. Jana Dzięgielewskiego, Warszawa 2013.

Kołodziej R., Prawo do protestu w praktyce sejmowej i sejmikowej w czasach Jana III Sobieskiego, „Biblioteka Epoki Nowożytnej” 2016, nr 4, s. 71-96.

Kołodziej R., Reforma procedury sejmowej w świetle anonimowej polemiki przed sejmem 1683 r. [w:] Sic erat in fatis. Studia i szkice historyczne dedykowane Profesorowi Bogdanowi Rokowi, t. 2, Toruń 2012.

Kołodziej R., Sejm elekcyjny w 1674 roku - precedens w procedurze sejmowej? [w:] Wokól wolnych elekcji w państwie polsko-litewskim XVI-XVIII w., red. M. Markiewicz, D. Rolnik, F. Wolański, Katowice 2016. 
Kołodziej R., Sejm z 22 grudnia 1693 roku, „Wieki Stare i Nowe” 2016, t. 10, s. 47-76.

Kołodziej R., Specyfika funkcjonowania sejmu Rzeczypospolitej w czasach Jana III Sobieskiego [w:] Między barokiem a oświeceniem. Parlamentaryzm, red. B. Krysztopa-Czupryńska, J. Kiełbik, Olsztyn 2016.

Konieczna D., Pomiędzy Pacami, Radziwitłami i Sapiehami - polityczne wybory Aleksandra Hilarego Polubińskiego za panowania Jana III, „Klio” 2015, 35, nr 4, s. 3-18.

Konopczyński W., Liberum veto. Studium porównawczo-historyczne, Kraków 2002.

Krupa J., Rady senatu za Jana III Sobieskiego (1674-1696), „Studia Historyczne” 1992, nr 35, z. 3, s. 307-329.

Majewski A.A., Aleksander Hilary Polubiński (1629-1679), marszatek wielki litewski. Działalność polityczno-wojskowa, Warszawa 2017.

Markiewicz M., Rzeczpospolita bez sejmu. Funkcjonowanie państwa [w:] Między barokiem a oświeceniem. Nowe spojrzenie na czasy saskie, red. K. Stasiewicz, S. Achremczyk, Olsztyn 1996.

Maroń J., Sejmy z lat 1688-1689, mps pracy doktorskiej, Biblioteka IH UWr.

Matwijowski K., Pierwsze sejmy z czasów Jana III Sobieskiego, Wrocław 1976.

Matwijowski K., Sejm grodzieński 1678-1679, Wrocław 1985.

Matwijowski K., Senat w czasach Jana III Sobieskiego [w:] Senat w Polsce. Dzieje i teraźniejszość, red. K. Matwijowski, J. Pietrzak, Warszawa 1993.

Nycz M., Geneza reform skarbowych sejmu niemego. Studium z dziejów skarbowo-wojskowych z lat 1697-1717, Oświęcim 2016.

Ochmann-Staniszewska S., Staniszewski Z., Sejm Rzeczypospolitej za panowania Jana Kazimierza Wazy. Prawo - doktryna - praktyka, t. 2, Wrocław 2000.

Olszewski H., Praktyka limitowania sejmików, „Czasopismo Prawno-Historyczne” 1961, nr 13, z. 1, s. 33-55.

Olszewski H., Sejm konny. Rzecz o funkcjonowaniu ideologii demokracji szlacheckiej $w$ dawnej Polsce, „Czasopismo Prawno-Historyczne” 1985, nr 37, z. 2, s. 225-242.

Olszewski H., The Political System and Political Thought in Poland During the Reign of John Sobieski, „Acta Poloniae Historica” 1985, nr 52, s. 87-103.

Olszewski H., The Political System and Political Thought in Poland During the Reign of John Sobieski, „Acta Poloniae Historica” 1985, nr 52, s. 87-103.

Olszewski H., Ustrój i doktryna w Rzeczypospolitej czasów Jana III Sobieskiego, „Studia Historyczne" 1985, nr 26, s. 15-28.

Piwarski K., Projekty reformy państwa za Jana III Sobieskiego [w:] Studia historyczne ku czci Stanisława Kutrzeby, t. 1, Kraków 1938.

Przyboś A., Michał Korybut Wiśniowiecki 1640-1673, Kraków 2007.

Sawicki M., Dom sapieżyński 1666-1685. Droga do hegemonii w Wielkim Księstwie Litewskim, Opole 2016.

Trawicka Z., Sejmik województwa sandomierskiego w latach 1572-1695, Kielce 1985.

Ujma M., Sejmik lubelski 1572-1696, Warszawa 2003.

Wierzbicki L., O zgodę w Rzeczypospolitej. Zjazd warszawski i sejm pacyfikacyjny 1673 r., Lublin 2006.

Wierzbicki L., Pospolite ruszenie w Polsce $w$ drugiej połowie XVII wieku. Ostatnie wyprawy z lat 1670-1672, Lublin 2011.

Woliński J., Epilog elekcji 1674 r., Kraków 1952.

Zwierzykowski M., Komisja Skarbowa Poznańska. Z dziejów sejmikowej administracji i sądownictwa skarbowego w Wielkopolsce w XVII i XVIII w., Poznań 2003. 